\title{
DEMOKRASI DALAM PANDANGAN M. QURAISH SHIHAB
}

\author{
Suci Mubriani \\ Universitas Islam Negeri (UIN) Sunan Kalijaga Yogyakarta \\ Email: sucimubriani@gmail.com \\ Imroatun Koniah \\ Universitas Islam Negeri (UIN) Sunan Kalijaga Yogyakarta \\ Email: imroatunkoniah97@gmail.com
}

\begin{abstract}
This research discusses democracy in the pandagan M. Quraysh Shihab. The reason behind this writing is that the author wants to spread democracy from a different point of view, namely from the Indonesian interpreter, namely $M$. Quraysh Shihab through his interpretation of the verses of the Qur'an. The formulation of this research problem is M. Quraysh Shihab's view of democracy. The purpose of this study was to find out what M. Quraysh Shihab said about democracy. Research is the study of figures, research methods used literature. The primary data of the work was written by $M$. Quraysh Shihab and secondary data in the form of writings of others about the thought of M. Quraysh Shihab. The results of M. Quraysh Shihab's research do not give a sense of democracy. But say joint decisions or so-called shura are a common feature of democracy. He argued that the implementation of democratic principles in Islam is different from that understood and practiced in Western countries. interpret the verses on shura namely: al-Baqarah verse 233, Äli 'Imrān verse 159, asy-Syūrā verse 38 . The result of his interpretation is: First deliberation begins from the family. God is All-forgiving, Allmerciful. Third, the problem that can be dimusyawarakan is a problem that has no provisions in the Qur'an and Sunnah.
\end{abstract}

Keywords: Democracy, Views, M. Quraysh Shihab, Shura.

\section{A. Pendahuluan}

Penelitian ini membahas tentang pandangan M. Quraish Shihab tentang demokrasi. Demokrasi merupakan salah satu isu populer sampai saat ini. Indikasi nyata dari isu populer tersebut terlihat bahwa mayoritas negara di dunia memakai demokrasi menjadi sistem pemerintahan dengan berbagai model. Bentuk pelaksanaan demokrasi suatu negara dipengaruhi oleh kondisi historis, ideologi politis, cultural, sosiologis yang ada di negara tersebut.

Secara garis besar terdapat tiga kelompokkan pemikiran tentang wacana Islam dan demokrasi: ${ }^{1}$ Pertama, Islam dan demokrasi adalah dua sistem yang berbeda, karena demokrasi sebagai konsep barat tidak tepat untuk dijadikan sebagai acuan dalam hidup bermasyarakat, berbangsa dan bernegara. Islam sebagai agama yang kaffah (sempurna) tidak saja mengatur persoalan keimanan (akidah) dan ibadah, melainkan mengatur segala aspek kehidupan umat manusia.

Kedua, Islam berbeda dengan demokrasi apabila demokrasi didefinisikan secara prosedural seperti dipahami dan dipraktekkan di negara-negara

1 Ubaedillah. dkk, Pendidikan Kewargaan (Civic Education) Demokrasi Hak Asasi Manusia dan Masyarakat Madani, (Jakarta: ICCE UIN Syarif Hidayatullah, 2000). h. 159-157. 
barat.Kelompok ini menyetujui adanya prinsip-prinsip demokrasi dalam Islam. Dalam pandangan kelompok ini, demokrasi adalah konsep yang sejalan dengan Islam setelah diadakan penyesuaian penafsiran terhadap konsep demokrasi itu sendiri. ${ }^{2}$ Ketiga, sistem nilai yang membenarkan dan mendukung sistem politik demokrasi seperti yang dipraktikkan negara-negara maju. Islam di dalam dirinya demokratis tidak hanya karena prinsip syura (musyawarah), tetapi juga karena adanya konsep ijtihad dan ijma' (konsensus).

Di Indonesia salah satu tokoh yang memaparkan tentang demokrasi adalah $\mathrm{M}$. Quraih Shihab melalui menafsirkan ayat-ayat Al-Quran. Ia bukanlah seorang yang memiliki latar belakang pelaku atau pemikir politik. Ia adalah seorang ulama tafsir kontemporer Indonesia. Ia tidak menulis pemikiran politiknya secara khusus dalam sebuah buku. Salah satu pemikirannya tentang hubungan agama dan negara yang terdapat di berbagai tulisannya, terutama dalam karya mumentalnya Tafsīr alMisbāh, ketika manafsirkan ayat-ayat yang berkaitan dengan politik ketatanegaraan.

\section{B. Pembahasan}

\section{B.1. Demokrasi dalam Pandangan M. Quraish Shihab}

Menurut M. Quraish Shihab Al-Quran dan sunnah menetapkan beberapa prinsip pokok berkaitan dengan kehidupan politik, seperti al-syura, keadilan, tanggung jawab, kepastian hukum, jaminan haq al-'ibad (hak-hak manusia), dan lainlain, yang kesemuanya memiliki kaitan dengan syura atau demokrasi. ${ }^{3}$ M. Quraish Shihab mengatakan bahwa:

"Allah memberikan kebebasan kepada manusia untuk memilih sendiri jalan yang dianggapnya baik, mengemukakan pendapatnya secara jelas dan bertanggung jawab. Kebebasan berpendapat, termasuk kebebasan memilih agama, adalah hak yang dianugerahkan Allah kepada setiap insan. Hal yang dikemukakan ayat Al-Quran merupakan salah satu benih dari ajaran demokrasi, hal mana kemudian akan nampak dengan jelas dalam petunjuk-petunjuk kitab suci. Salah satu yang dapat dikemukakan di sini adalah pengalaman Nabi saw dalam peperangan Uhud serta kaitannya dengan ayat yang memerintahkan musyawarah."4

Pernyataan diatas dapat disimpulkan bahwa M. Quraish Shihab memaparkan nilai-nilai dasar yang ada dalam demokrasi. M. Quraish Shihab tidak memberikan pengertian demokrasi, namun mengatakan keputusan diambil berdasarkan pandangan mayoritas merupakan ciri umum dari demokrasi. Sebab demokrasi menurut beliau mempunyai pengertian yang beranekaragam. Seperti yang diungkapkan oleh M. Quraish Shihab bahwa:

"Apabila kita bermaksud membandingkan syura dengan demokrasi, tentunya perlu dijelaskan apa yang disebut demokrasi. Namun untuk tidak memasuki perincian tentang makna demokrasi yang beraneka ragam, dapat dikatakan bahwa manusia mengenal tiga

2 Idris Thaha, Demokrasi Religius: Pemikiran Politik Nurcholish Madjid dan Amien Rais, (Jakarta: Teraju, 2005). h. 7-8.

${ }^{3}$ M. Quraish Shihab, Wawasan Al-Qur'an: Tafsir Tematik atas Berbagai Persoalan Umat. (Bandung: Mizan, 2007), h. 635.

4 Ibid, h. 498-501. 
cara menetapkan keputusan yang berkaitan dengan kehidupan masyarakat, yaitu keputusan yang ditetapkan oleh penguasa, keputusan yang ditetapkan berdasarkan pandangan minoritas dan keputusan yang ditetapkan berdasarkan pandangan mayoritas, dan ini biasanya menjadi ciri umum demokrasi." 5

Dapat dikatakan bahwa, M. Quraish Shihab tidak memberikan pengertian demokrasi, namun mengatakan keputusan diambil berdasarkan pandangan keputusan yang diambil berdasarkan pandangan mayoritas menurut M. Quraish Shihab disebut syura, pernyataan tersebut berdasarkan kutipan di bawah ini mayoritas merupakan ciri umum demokrasi. Sebab demokrasi menurut beliau mempunyai pengertian yang beranekaragam:

"Syura yang diwajibkan oleh Islam tidak berwujud seperti bentuk pertama, karena hal itu justru menjadikan syura lumpuh. Bentuk kedua juga tidak sesuai dengan makna syura, sebab apa keistimewahan pendapat minoritas yang mengalahkan pandangan mayoritas?. Walaupun syura di dalam Islam membenarkan pendapat mayoritas, tetapi tidaklah mutlak. Keputusan jangan langsung diambil berdasarkan pandangan mayoritas setelah dilakukan musyawarah, tetapi hendaklah berulang-ulang hingga dicapai kesepakatan."6

M. Quraish Shihab membahasan tentang demokrasi ini ketika ia menafsirkan ayat-ayat tentang syura. Secara tekstual, memang tidak banyak ayat Al-Quran yang membicarakan tentang syura atau musyawarah yang menjadi landasan perkembangan sistem demokrasi modern. Ada tiga ayat yang secara jelas menyebut kata syura yang secara tersirat berisi pesan untuk mengutamakan sistem demokrasi dalam segala aspek kehidupan yaitu:

1. Q.S. Al-Baqarah ayat 233

"A pabila keduanya ingin menyapih (sebelum dua tahun) dengan kerelaan keduanya dan permusyawaratan. 7

Ayat ini membicarakan bagaimana seharusnya hubungan suami istri saat mengambil keputusan yang berkaitan dengan rumah tangga dan anak-anak, seperti menyusui anak. Anjuran penyusuan selama dua tahun ditekankan seakan ia perintah wajib. Namun jika suami dan istri berbeda pendapat mengenai lama waktu menyusui, perbedaan tersebut dapat dimusyawarakan untuk disepakati. Tetapi hendaknya jangan berlebih dari dua tahun karena dua tahun telah dinilai sempurna oleh Allah SWT. ${ }^{8}$

Pada ayat di atas, Al-Quran memberikan petunjuk agar persoalan itu (dan juga persoalan-persoalan rumah tangga lainnya) dimusyawarahkan antara suami istri dengan mendiskusikan serta mengambil keputusan yang terbaik. ${ }^{9}$ Dapat ditarik kesimpulan bahwa syura yang merupakan salah satu prinsip-

${ }^{5}$ M. Quraish Shihab, Wawasan Al-Qur'an: Tafsir Tematik..., h. 501.

6 Ibid, h. 636.

7 Departemen Agama RI, al-Qur'an dan Terjemahannya, (Jakarta: Pustaka Alfatih, 2009), h. 37.

${ }^{8}$ M. Quraish Shihab, Tafsìr al-Misbäh: Pesan Kesan dan Keserasian al-Qur'an, (Jakarta: Lentera Hati, 2002), h. 609-610.

${ }_{9} \mathrm{Ibid}, \mathrm{h} .681$. 
prinsip umum demokrasi dimulai dari unit terkecil dari masyarakat yaitu keluaga.

2. Q.S. Ali Imran ayat 159

"Dan bermusyawaratlah dengan mereka dalam urusan itu."10

Perintah bermusyawarah diatas diturun setelah peristiwa menyedihkan pada perang Uhud. Pada saat itu, menjelang pertempuran, Rasulullah saw mengumpulkan para sahabatnya untuk memperbincangkan strategi menghadapi musuh yang tengah berada dalam perjalanan dari Mekah untuk menyerang Madinah. Rasulullah saw sendiri berpendapat agar bertahan di kota Madinah. Sementara itu, para sahabat, terutama dari kalangan muda, mendesak Rasulullah saw dan umat Islam agar keluar dari Madinah dan menghadapi musuh. Pendapat ini didukung oleh mayoritas sahabat sehingga Rasulullah saw pun menyetujuinya. Namun sayang, keputusan yang dihasilkan secara demokratis tersebut berakhir memilukan. Peperangan tersebut berakhir dengan kekalahan umat Islam dan gugurnya sekitar tujuh puluh orang sahabat. ${ }^{11}$

Dengan memerhatikan asbabun nuzul di atas, tergambar jelas pesan inti ayat Q.S. Ali ‘Imran ayat 159. Ayat ini berisi pesan kepada Rasulullah saw secara khusus dan umat Islam secara umum untuk mempertahankan dan membudayakan musyawarah, walaupun terkadang pendapat mayoritas tersebut tidak selamanya benar dan tepat. Namun demikian, kekeliruan mayoritas lebih dapat ditoleransi dan menjadi tanggung jawab bersama dari pada kesalahan yang bersifat individual. Salah satu yang menjadi penekanan pokok ayat ini adalah perintah melakukan musyawarahkan. Ini penting karena petaka yang terjadi di Uhud didahui oleh musyawarah serta disetujui oleh mayoritas. Kendati demikian, hasilnya sebagaimana telah diketahui, adalah kegagalan. Hasil ini boleh jadi mengantarkan seseorang untuk berkesimpulan bahwa musyawarah tiak perlu diadakan. Apalagi bagi Rasulullah saw nah dari, ayat ini dipahami sebagai pesan untuk melakukan musyawarah. Kesalahan yang dilakukan setelah musyawarah, tidak sebesar kesalahan yang dilakukan tanpa musyawarah dan kebenaran yang diraih sendirian, tidak sebaik kebenaran yang diraih bersama. ${ }^{12}$

Pada ayat ini, tiga sifat dan sikap secara berurutan disebut dan diperintahkan kepada Nabi Muhammad saw untuk beliau laksanakan sebelum musyawarah. Penyebutan ketiga hal itu, dari segi konteks turunnya ayat, mempunyai makna tersendiri yang berkaitan dengan perang Uhud. Namun, dari segi pelaksanaan dan esensi musyawarah, ia perlu menghiasi diri Nabi Muhammad saw dan setiap orang yang melakukan musyawarah. Setelah itu sikap yang harus diambil setelah adanya kesepakatan dan bulatnya tekat adalah berlaku lemah lembut, memaafkan dan bertawakal kepada Allah. ${ }^{13}$

\footnotetext{
10 Departemen Agama RI, al-Qur'an dan Terjemahannya..., h. 71.

${ }_{11}$ M. Quraish Shihab, Wawasan Al-Qur'an: Tafsir Tematik..., h. 626.

12 M. Quraish Shihab, Tafsìr al-Misbāh..., h. 312-313.

13 Ibid, h. 313
} 
Dapat dikatakan untuk mendapatkan hasil yang diinginkan dicapai dalam musyawarah, pihak-pihak yang ikut serta dalam musyawarah tersebut, tidak hanya mempunyai pikiran yang jernih tetapi juga ilham dan bimbingan dari Allah. Hal ini didapat melalui bertawakal kepada-Nya. Hasil musyawarah terapkan berdasarkan kesepakatan, dan selanjutnya menyerahkan semua kepada Allah.

3. Q.S. Asy-Syura ayat 38

"Dan sedang urusan mereka (diputuskan) dengan musyawarat antara mereka."

Menurut M. Quraish Shihab, ayat ini berisi pujian kepada kelompok Anshar yang membela Nabi Muhammad saw ketika peran Uhud dan menyepakati hal tersebut melalui musyawarah (syura) yang dilaksanakan di rumah Abu Ayyūb al-Ansāri. Walaupun khitab ayat ini bersifat khusus, namun pesan intinya berlaku universal. Perintah untuk bermusyawarah yang terdapat dalam ayat di atas turun setelah terjadi peristiwa menyedihkan dalam perang Uhud. ${ }^{14}$ Ayat ini berkaitan dengan masyarakat yakni mereka memutuskan urusan mereka dengan musyawarah, tidak ada di antara mereka yang bersifat otoriter dengan memaksakan pendapat. Batasan masalah yang bisa dimusyawarakan hanya pada urusan yang belum ada kentuannya dalam AlQuran dan Sunnah.

Penafsiran M. Quraish Shihab tentang syura pada ketiga ayat diatas, akan penulis membandingkan dan menyamakan dengan mufasir lainnya. Agar dapat memperjelas makna dari syura itu sendiri sebagai ciri umum demokrasi. Dimana syura tersebut merupakan ciri umum dari demokrasi. Tokoh-tokoh tersebut seperti Wahbāh az-Zuāilī, Hamka, dan al-Qurtubi. Alasan penulis memilih pendapat tokoh-tokoh diatas karena penulis menggap pendapat mereka dapat mengungatkan penafsiran $\mathrm{M}$. Quraish Shihab karena memiliki kemiripan hasil penafsiran selain itu juga berasal dari tempat dan periode yang sama.

Q.S. Al-Baqaroh ayat 233 memiliki kesamaan dengan penafsiran dari Wahbāh az-Zuāilī (1932-2015M), Hamka (1908-1981M) dan al-Qurtubi (w.671H) bahwa ayat ini dapat menjadi dalil kebolehan berijtihad dalam hukum (Qurthubi 2006, 366). Kedua orang tua bermusyawarah untuk kemaslahan anaknya. Kemaslahatan itu diukur berdasar hakikat dan keyakinan orang tua. ${ }^{15}$ Pada ayat ini mengandung makna rela dan damai, dalam kedua kalimat ini terdapat bahwa, di dalam dasar kerelaan hati dan saling menghargai di antara suami istri, demi kemaslahatan anak. ${ }^{16}$

Ada tiga sikap bagi yang harus dimiliki oleh orang yang terlibat dalam musyawarah. Tiga sikap itu adalah berlaku lemah lembut, memaafkan dan bertawakal kepada Allah seperti yang diungkapkan oleh M. Quraish Shihab pada surat ali Imran ayat 159. Kriteria orang yang layak untuk diajak musyawarah dalam masalah hukum adalah memiliki ilmu dan mengamalkan ajaran agama. Dalam

14 M. Quraish Shihab ,Wawasan Al-Qur'an: Tafsir Tematik..., h. 619.

15 Wāhbāh al-Zuhāilī, Tafsīr al-Munìr Fì al-'Āqīdah wa al-Syarī'āh Wa al-Manhạaj, (Beirut: Dār alFikr. 2009). h. 366.

16 Hamka, Tafsir Al-Azhar, (Jakarta: Pustaka Panjimas, 1984), h. 235-236. 
bermusyawarah pasti ada perbedaan pendapat. Maka, orang yang bermusyawarah harus memperhatikan perbedaan itu dan memperhatikan pendapat yang paling dekat dengan Al-Quran dan Sunnah. Setelah semua pertimbangan beliau dengarkan dan pertukaran pikiran tentang mudharat dan manfaat sudah selesai, niscaya beliau sudah mempunyai pertimbangan dan penilaian. Setelah itu baru beliau mengambil keputusan. Selanjutnya ketetapan yang yang didapat akan kuat dan Allah akan menolong serta menunjuki mereka kearah yang lebih baik. ${ }^{17}$

Surat asy-Syura ayat 38 berkaitan dengan aturan yang khusus dan umum. Orang yang berada dalam forum musyawarah tidak secara sendiri-sendiri dalam suatu pendapat yang bersifat umum, seperti: mengangkat pemimpin, persoalan mengatur negara, membuat peraturan untuk kemaslahatan negara dan memberitahukan peran seorang pemimpin dan hakim. Nabi adalah orang yang sering bermusyawarah dengan sahabatnya. Para sahabat telah menempuh metode dalam persoalan yang besar, seperti: penggantian khalifah, memerangi orang murtad, menghistimbatkan berbagai hukum syar'i terhadap persoalan yang baru muncul. ${ }^{18}$

Musyawarah termasuk salah satu kaidah syariat dan penetapan hukumhukum. Barangsiapa yang tidak bermusyawarah dengan ulama, maka wajib diberhentikan. Tidak ada pertentangan tentang hal ini. Allah SWT memuji orangorang yang beriman karena mereka suka bermusyawarah berdasarkan ayat di atas ${ }^{19}$. Urusan yang di maksud pada ayat diatas adalah urusan pribadi dan urusan yang menyangkut kepentingan bersama. Mengenai urusan bersama di musyawaratkan bersama,agar terasa lebih mudah. Anjuran bermusyawarah ini disambung dengan "mereka manafkahkan sebagian dari rizki yang kami berikan kepada mereka" (ujung ayat asySyūrā ayat 38) dikarenakan suatu musyawarat tentang urusan bersama tidak akan mendapatkan hasil yang diharapkan kalau orang tidak mau menafkahkan sebagian harta mereka untuk kepentingan bersama. ${ }^{20}$

Secara tersurat tidak tergambar sedikitpun sistem demokrasi dalam ayat-ayat Al-Quran di atas. Akan tetapi, jika dicermati dan ditelaah secara seksama, ayat-ayat Al-Quran di atas berisi anjuran kepada umat Islam untuk menjunjung tinggi dan membudayakan sikap demokratis yang secara tersurat digambarkan dalam bentuk perintah untuk selalu bermusyawarah dalam berbagai aspek kehidupan. Inilah pesan inti yang menjadi ideal moral dari ayat-ayat Al-Quran tentang demokrasi di atas. Syura dan demokrasi merupakan wacana yang mengalami perkembangan. Dengan demikian, petunjuk Al-Quran mengenai syura amat singkat dan tidak banyak.

Petunjuk mengenai pola dan bentuk syura pun tidak di sebutkan secara rinci dalam Al-Quran. Pola dan bentuk syura itu sendiri diserahkan kepada masyarakat, berdasarkan budaya dan kondisi sosial daerah masing-masing menyatakan bahwa:

"Al-Quran tidak merinci atau meletakkan pola dan bentuk musyawarah tertentu. Paling tidak, yang dapat disimpulkan dari teks-teks Al-Quran hanyalah bahwa urusan yang berkaitan dengan mereka. Perincian keterlibatan, pola dan caranya diserahkan

${ }^{17} \mathrm{Al}$ Qurthubī, al-Jami' li Ahkām al-Qur'an. Terj. Dudi Rosyadi dkk, (Jakarta: Pustaka Azzam, 2008), h. 623-627.

18 Zūhailī 2009, Qadāyā al-Fiqh wa al-Mu'asìr, (Damaskus: Darl Fikr, 2006), h. 140-144.

19 Ibid, h. 623-627.

20 Hamka, Tafsir Al-Azhar..., h. 36. 
kepada masing-masing masyarakat, karena satu masyarakat dapat berbeda dengan masyarakat lain. Bahkan masyarakat tertentu dapat mempunyai pandangan berbeda dari suatu masa kemasa lain. Sikap Al-Quran seperti itu memberikan kesempatan ke pada setiap masyarakat untuk menyesuaikan sistem syura-nya dengan kepribadian, kebudayaan dan kondisi sosialnya."21

Pada sebuah wawancara M. Quraish Shihab dengan tabloaid Republika Rabu 23 Januari 2008, membahas demokrasi dalam pandangan M. Quraish Shihab. Beliau mengatakan Islam jelas bukan hanya mendukung demokrasi, dia mensyaratkan. Kalau mendukung, ini seakan-akan datang dari luar yang didukung. Sebenarnya demokrasi yang diajarkan Islam justru lebih dulu, lebih jelas dari pada demokrasi yang berasal dari Barat (Yunani Kuno). ${ }^{22}$

Istilah demokrasi itu dikenal di Barat dari bahasa Yunani. Tapi sebenarnya dalam Islam yang dinamakan syura adalah pada mulanya berarti mengeluarkan madu dari sarangnya. Jadi, orang-orang demokrasi itu dipersamakan dengan lebah yang menghasilkan madu. Lebah punya keistimewaan, dia tidak makan kecuali yang baik. Dia tidak mengganggu, kalau ia diaganggu kalau pun dia menyengat, sengatannya obat. Hasilnya selalu baik, bermanfaat. Itulah yang dicari. Kemudian dari syura lahirlah mencari pendapat yang baik seperti baiknya madu. Di mana pun madu ditemukan, itu kita ambil. Baik dari yang mendengar pendapat maupun yang menyampaikan pendapat.

Konsep demokrasi yang dicetuskan oleh bangsa barat itu hanya sebatas konsep, dan tidak dapat diterapkan karena terbukti masih banyak terjadi ketidakadilan dan pelanggaran hak asasi manusia. Oleh karena itu menurut Wāhbah Zūhailī demokrasi itu adalah konsep yang dibentuk berdasarkan musyawarah. Kemudian dibangun untuk mencapai kebaikan untuk manusia, negara di dunia dan akhirat secara bersamaan. Pembuat hukum bukanlah kewenangan rakyat atau wakil rakyat tetapi hanyalah kewenangan mutlak Allah SWT.23

Islam memiliki peran yang sangat besar dalam mengembangkan demokrasi karena itu dalam Al-Quran ada pujian tentang orang-orang yang bermusyarawah bahwa persoalan mereka itu selalu mereka selesaikan dengan musyawarah. Bahkan musyawarah itu diperintahkan dalam unit masyarakat yang terkecil yakni keluarga. Demokrasi itu bukan hanya ada pada level pemerintahan atau level negara, tetapi musyawarah atau berdemokrasi yang diajarkan adalah dalam level yang serendahrendahnya yaitu dalam keluarga.

Dalam hal Penafsiran ayat M. Quraish Shihab cendrung menekankan pentingnya penggunaan metode tafsir māudu'î (tematik), yaitu penafsiran dengan acara menghimpunan sejumlah ayat Al-Quran yang tersebar dalam berbagai surat yang membahas masalah yang sama. Kemudian menjelaskan pengertian menyeluruh dari ayat-ayat tersebut dan selanjutnya menarik kesimpulan sebagai jawaban terhadap masalah yang menjadi pokok bahasan. Menurutnya, dengan metode ini dapat diungkapkan pendapat-pendapat Al-Quran tentang berbagai masalah

21 M. Quraish Shihab ,Wawasan Al-Qur'an: Tafsir Tematik..., h. 637-638.

22 Damanhuri Zuhri, "Prof. Dr. H. M. Quraish Shihab Islam Mensyaratkan Demokrasi”, Edisi 09 januari 2009. http:/ / Republika.co.id diakses 21 November 2020.

23 Wāhbāh al-Zuhaili, Qadāyā al-Fiqh wa al-Mu'asìr, (Damaskus: Darl Fikr, 2006), h. 503. 
kehidupan, sekaligus dapat dijadikan bukti ayat Al-Quran sejalan dengan perkembangan peradaban masyarakat. ${ }^{24}$

Disamping itu sumber utama yang penulis pakai yaitu tafsir al-Misbâh penulisannya merujuk kepada karya-karya baik itu ulama klasik maupun kotemporer. Adapun sumber-sumber yang dijadikan oleh M. Quraish Shihab dalam menulis kitab tafsir ini meliputi: Tafsīr Ibrāhīm ibn 'Umar al-Bīqa'i (w.885H-1480M) yang tafsirnya masih berbentuk manuskrip dan dijadikan sebagai referensi dan dijadikan sebagai dan dijadikan referensi dalam menyusun desertasinya. Sementara referensi yang digunakan dalam mencari makna pada tafsīr al-Misbāh diantara: Shāhīh Bukharīh, Shāhīh Mūslīm karya ibn Hājjāj, Nazhām al-Dūrār karya Ibrāhim ibn 'Umār al-Bīqa'i, dan banyak yang lainya.

Diantara banyak literatur yang digunakan M. Quraish Shihab yang paling mendominasi adalah tafsir al-Mizan karya Hūsaīn al Thābathāba'i, sebab hampir setiap penafsirannya selalu mengutip pendapat Thābathāba'i. Dalam mengutip pendapat-pendapat mufasir sebelum ia cukup kritis dalam menerima pendapat tersebut. Apabila pendapat tersebut tidak sesuai menurut logikanya maka pendapatnya itu ditolak. Jadi kurang lebih pendapat M. Quraish Shihab banyak dipengaruhi oleh beberapa referensi yang ia pakai. Dari masa kemasa selalu saja muncul penafsiran baru sejalan dengan perkembangan ilmu dan tuntutan kemajuan.

Meski begitu ia tetap mengingatkan perlunya sikap teliti dan ekstra hati-hati dalam menafsirkan Al-Quran. Sehingga seorang tidak mudah mengklaim suatu pendapat sebagai pendapat dari Al-Quran. M. Quraish Shihab juga seorang yang konsisten, ini dapat dilihat dalam setiap karya tulisnya, jika ia berpendapat A dari awal maka seterusnya akan seperti itu. Meskipun pendapatnya tersebut mendapatkan banyak kritikan, ia tetap mempertahankan pendapatnya. Pola berfikir M. Quraish Shihab ini juga dipengaruhi oleh cara dan proses belajar yang pernah ia tempuh melalui jenjang pendidikannya.

Dapat dilihat dari cara ia berpendapat ia merupakan seorang pembaru sebab ia dapat beradaptasi dengan pelakasanaan demokrasi pada saat ini. Hal ini dapat dilihat jika M. Quraish Shihab adalah seorang yang berpikir luas, ia dapat menyesuikan pendapatnya dengan perkembangan keadaan dan kondisi masyarakat khususnya masyarakat Indonesia yang mempunyai pola pikir yang terbuka untuk menerima suatu hal yang baru. M. Quraish Shihab memberikan kontribusi pemikiran tentang demokrasi. Menurutnya, Al-Quran memberikan petunjuk tentang persoalan yang mengalami perkembangan dan perubahan dalam bentuk global (prinsip-prinsip umum). Tujuannya adalah agar petunjuk tersebut dapat menampung segala perubahan dan perkembangan sosial budaya masyarakat. Seperti pandangannya tentang demokrasi ini, sebab sebagian ulama lainnya menganggap Islam dan demokrasi adalah dua sistem yang berbeda,

Demokrasi sebagai konsep barat tidak tepat untuk dijadikan sebagai acuan dalam hidup bermasyarakat, berbangsa dan bernegara. Islam sebagai agama yang kaffah (sempurna) tidak saja mengatur persoalan keimanan (akidah) dan ibadah, melainkan mengatur segala aspek kehidupan umat manusia. Petunjuk mengenai

24 Wikipedia.org, "Muhammad Quraish Shihab", https://id.m.wikipedia.org /wiki/Muhammad_Quraish_Shihab diakses 21 November 2020. 
pola dan bentuk syura pun tidak di sebutkan secara rinci dalam Al-Quran. Pola dan bentuk syura itu sendiri diserahkan kepada masyarakat, berdasarkan budaya dan kondisi sosial daerah masing-masing. Seperti halnya yang diperaktekkan negara muslim. Seperti halnya praktek syura atau musyawarah di Indonesia dilaksanakan dengan model yang beragam, tergantung budaya masing-masing daerah, dan tujuan dari musyawarah itu sendiri. Sehingga masyarakat muslim dapat berpartisipasi dalam penerapan demokrasi di dalam kehidupan bermasyarakat muslim. Penerapan demokrasi dalam masyarakat muslim Indonesia dapat menjadi model bagi masyarakat muslim lainnya.

M. Quraish Shihab memang bukan satu-satunya pakar Al-Quran di Indonesia, tetapi kemampuannya menerjemahkan dan menyampaikan pesan-pesan masa kini membuatnya lebih dikenal. M. Quraish Shihab juga dikenal sebagi penulis yang handal. Berdasarkan pada latar belakang keilmuan yang ia tempuh, ia mampu menyampaikan pendapat dan gagasan dengan bahasa yang sederhana. Tetapi pendapatnya lugas, rasional dan kecendrungan pemikiran yang moderat, ia tampil sebagai penceramah dan penulis yang bisa diterima oleh semua lapisan masyarakat. Selain itu ia juga merupakan seorang aktivis diberbagai bidang seperti yang telah penulis bahas pada bab tiga, dimana kegiatan tersebut bertujuan untuk mengembangan potensi keilmuan masyarakat di Indonesia. Penjelasan yang penulis paparkan diatas menggambarkan alasan dari pandangan M. Quraish Shihab tentang tentang Syura benih dari demokrasi itu sendiri. Seperti yang telah penulis jelaskan diatas.

\section{B.2. Perbedaan Antara Demokrasi dengan Syura Menurut M. Quraish Shihab}

M. Quraish Shihab membedakan demokrasi dengan syura dari tiga sudut pandang yaitu:

1. Pihak-pihak yang ikut serta dalam musyawarah

Pihak yang mengikut musyawarah adalah orang yang memiliki akhalak yang mulia, ia mengungkapkan bawa"Syura dilaksanakan di dalam Islam dilaksanakan oleh orang-orang pilihan yang memiliki sifat-sifat terpuji serta tidak membawa kepentingan pribadi atau golongan. Sekalipun diantara mereka tidak menerima keputusan tersebut itu dapat mejadi indikasi adanya sisi-sisi yang kurang berkenan di hati mereka (minoritas) sehingga perlu dibicarakan lebih lanjut agar mencapai mufakat (untuk menemukan "madu" atau yang terbaik). Ini merupakan salah satu perbedaan syura di dalam Islam dengan demokrasi secara umum." 25

Sifat yang dimaksud disini adalah sikap lemah lembut, tidak kasar, tidak berhat keras dan pemaaf (berhati lapang). Orang yang bermusyawarah harus menyiapkan mental untuk bersedia memberi maaf, mungkin saja ketika bermusyawarah terjadi perbedaan pendapat, atau keluar kalimat-kalimat yang

25 M. Quraish Shihab, Wawasan Al-Qur'an: Tafsir Tematik..., h. 636. 
menyinggung pihak lain. Jika orang yang bermusyawarah tidak memiliki sifat tersebut boleh jadi musyawarah akan menjadi pertengkaran. ${ }^{26}$

Sebuah riwayat menyatakan Nabi Muhammad saw pernah berpesan kepada Ali bin Abi Thalib yang berkaitan dengan sifat-sifat yang dilarang oleh Rasulullah saw ketika mengajak pihak-pihak yang akan diikut sertakan dalam musyawarah yakni sifat penakut, kikir dan berambisi, sebab sifat tersebut bermuara pada prasangka buruk terhadap Allah. ${ }^{27}$. Sifat-sifat Imam Ja'far ashShidiq berpesan, "Bermusyawarahlah dalam persoalan-persoalanmu dengan seseorang yang memiliki lima hal; akal, lapang dada, pengalaman, perhatian dan takwa.

M. Quraish Shihab menyatakan pihak yang melakukan musyawarah harus menyadari bahwa ketajaman analisa saja belumlah cukup, untuk mencapai hasil yang terbaik hubungan dengan tuhan harus harmonis, itu sebabnya hal yang harus mengiringi musyawarah adalah permohonan maghfirah dan ampunan Ilalhi, sebagaimana ditegaskan dalam QS. Ali-Imran ayat 159, "Setelah bermusyawarah selesai bulatkan tekad dan berserah diri kepada Allah." 28

Pada konteks memusyawarahkan persoalan-persoalan masyarakat, dipratekkan oleh Rasulullah sawsecara beragam. Terkadang beliau memilih orang-orang tertentu yang dianggap cakap dalam bidang yang dimusyawarahkan, terkadang melibatkan pemuka-pemuka masyarakat, bahkan menanyakan kesemua yang terlibat dalam sebuah masalah yang dihadapi. ${ }^{29}$ Sebab suatu, musyawarah tujuannya adalah untuk mencari kebenaran. Maka dari itu, yang berhak untuk menjadi anggota majelis syura ialah orang-orang yang berkompeten dalam bidangnya masing-masing, dan mereka ditunjuk oleh pemimpin. Merekalah yang memahami setiap permasalahan beserta solusinya dalam bidangnya masing-masing.

Sedangkan demokrasi tidak seperti itu, anggotanya dipilih oleh rakyat, merekalah yang mencalonkan para perwakilan mereka. Setiap anggota masyarakat, siapapun dia memiliki hak untuk dicalonkan dan mencalonkan. Setiap warga negara memiliki porsi yang sama dalam mengemukakan pendapat, baik dia seorang kafir, fasik (pelaku maksiat), ataupun sekuler ${ }^{30}$. Tidak mengheran bila di negara demokrasi, orang yang berbuat maksiatpun dapat menjadi anggota parlemen, atau berdemonstrasi menuntut kebebasan dalam menjalankan praktek kemaksiatannya. Seperti ungkapan M. Quraish Shihab pada sebuah acara di stasiun TV swasta mengatakan:

"Jangan bermusyawarah dengan sembarangan orang. Orang yang diminta pendapat harus dianggap sebagai lebah. Lebah ia tidak akan makan kecuali yang bagus, kalau ia hinggap disuatu tempat, ia tidak merusak. Lebah menghasilkan suatu yang sangat manis dan bermanfaat. Lebah tidak menggangu kecuali dia

${ }^{26}$ M. Quraish Shihab, Wawasan Al-Qur'an: Tafsir Tematik.., h. 634.

27 Ibid, h. 632.

${ }_{28}$ M. Quraish Shihab, Tafsìr al-Misbāh..., h. 34.

${ }^{29}$ Ibid, h. 633.

30 Salim Ali al-Bahansawi, Wawasan Sistem Politik Islam Asy Syari'ah al-Muftara 'Alaiha, Terj. Mustolah Maufur, (Jakarta: Pustaka al-Kautsar, 1996), h. 122-123. 
diganggu, dan jika ia menyengat, sengatannya menjadi obat. Dan kita harus yakin bahwa musyawarah dengan orang itu, berarti ia memiliki madu atau sesuatu yang bagus."

Dari penuturan M. Quraish Shihab di atas, tergambar ketika bermusyawarah harus memperhatikan orang yang diajak bermusyawarah. Pihak-pihak yang bermusyawarah hendaklah memiliki sifat yang terpuji bagaikan lebah, sebab Allah tidak akan memberikan petunjuk kepada orang kafir, zalim, melampaui batas dan orang fasik. Kriteria orang yang layak untuk diajak musyawarah dalam masalah hukum adalah memiliki ilmu dan mengamalkan ajaran agama.

2. Dari segi pengangkatan pimpinan

Syura dan demokrasi menetapkan bahwa pimpinan diangkat melalui kontrak sosial, namun syura di dalam Islam mengaitkannya dengan "perjanjian ilahi". Ini diisyaratkan oleh Allah SWT dalam firman-Nya Q.S. Al-Baqarah ayat 124 ketika mengangkat Nabi Ibrahim a.s sebagai imam:

"Dan (ingatlah), ketika Ibrahim diujiTuhannya dengan beberapa kalimat (perintah dan larangan), lalu Ibrahim menunaikannya. Allah berfirman: "Sesungguhnya aku akan menjadikanmu imam bagi seluruh manusia". Ibrahim berkata: "(Dan saya mohon juga) dari keturunanku" Allah berfirman: "Janji-Ku (ini) tidak mengenai orang yang zalim." 31

Seorang pemimpin yang dilantik mengikut sistem syura adalah seorang pemimpin yang mempunyai keperibadian yang baik serta bukan dari kalangan orang yang fasik maupun munafik. Dalam sistem syura pemilihan khalifah atau seseorang yang bakal memimpin negara adalah berdasarkan apa yang telah disarankan oleh Allah SWT dalam Al-Quran. Hal ini sejalan dengan apa yang disarankan dalam Al-Quran yang sering menyuruh umat Islam supaya mengikuti kebenaran dan menjaga kebaikan masyarakat manusia dengan tidak mengambil keputusan berdasarkan suara dan kehendak golongan mayoritas sebagai ukuran yang boleh diterima terutamanya dari segi pemilihan pemimpin.

Untuk mengankat kepala negara terdapat dua cara. Pertama cara pemilihan oleh ahl al-'aqd wa al hilli (mereka yang berwenang mengikat dan melepaskan) yakni para ulama, cendikiawan dan pemuka masyarakat atau disebut juga al-ikhtiyar. Kedua, cara penunjukkan atau waksiat oleh kepala negara yang sedang berkuasa. Sebelum pelaksanaan pemilihan lem baga pemilih mengadakan penelitian terlebih dahulu terhadap kandidat kepala negara apakah ia memenuhi persyaratan. Apabila calon telah memenuhi syarat kemudian ia diminta kesediannya ${ }^{32}$.

Menurut Al-Mawardi (976-1058M) seorang pemimpin diperuntukkan sebagai pengganti Nabi Muhammad SAW yang mempunyai fungsi untuk menjaga agama dan memelihara dunia. Pemberian jabatan pemimpin diberikan

31 Departemen Agama RI, Al-Qur'an dan Terjemahannya..., h. 19.

32 Al-Mawārdi, Al-ahkam As-sulthaniyyah, (Bairut: Dar al-Fikr, 2016), h. 1-3. 
kepada yang mampu menjaga umat. Ada beberapa syarat pengakatan imam yaitu:

a. Adil.

b. Mempunyai ilmu yang mampu berijtihad terhadap kasus-kasus dan hukuk-hukum.

c. Sehat indrawi (telinga, mata, dan mulut) yang dengannya ia mampu menangani langsung permasalahan yang telah diketahui.

d. Sehat organ tubuh dari cacat yang menghalanginya bertindak dengan sempurna dan cepat.

e. Wawasan yang membuatnya mampu memimpin rakyat dan mengelolah semua kepentingan.

f. Berani dan kesatria yang membuatnya mampu melindungi wilayah negara dan melawan musuh.

g. Nasab yaitu berasal dari Quraish berdasarkan nash-nash yang ada dan ijma' para ulama.

Di dalam Islampun terdapat syarat-syarat dewan pemilih yang harus mereka miliki:

a. Adil dengan segala syarat-syaratnya.

b. Ilmu yang membuatnya mampu mengetahui siapa yang berhak menjadi imam sesuai dengan kriteria yang legal.

c. Wawasan dan sikap bijaksana yang membuatnya mampu memilih siapa yang paling tepat menjadi imam (khalifah), dan paling efektif, serta paling ahli dalam mengelolah semua kepentingan.

Mengenai pernyataan Islam disorot tidak demokratis karena yang muncul adalah dinasti-dinasti, M. Quraish Shihab menjawab bahwa:

"Kita harus bedakan antara ajaran Islam dan sejarah Islam. Belum tentu apa yang dipraktekkan oleh penguasa-penguasa dan dinasti-dinasti Islam merupakan ajaran Islam yang murni. Kita harus bedakan antara Islam ajaran dan Islam politik. Soal kerajaan turun temurun itu, ada yang berkata itu bukan demokrasi tapi terserah kepada masing-masing masyarakat. Kalau mereka menyetujui itu, ya itu sudah salah satu bentuk demokrasi. Di Inggris juga kerajaan dan itu disetujui oleh masyarakat Inggris. Jadi, tidak otomatis kerajaan itu lantas dikatakan bertentangan dengan demokrasi sebagaimana tidak juga otomatis pemerintahan yang republik, itu otomatis demokrasi. Karena boleh jadi dalam prakteknya tidak seperti itu." 33

Dapat ditarik kesimpulan jika demokrasi disesuai dengan waktu dan tempat demokrasi itu sendiri diterapkan oleh sebuah pemerintahan.

3. Persoalan yang dapat dibahas dan diputuskan

Di dalam sistem demokrasi sekuler persoalan apapun dapat dibahas dan diputuskan. Tetapi dalam syura yang diajarkan dalam Islam, tidak dibenarkan untuk memusyarakan segala sesuatu yang telah ada ketetapannya dan tidak

33 Damanhuri Zuhri, "Prof. Dr. H. M. Quraish Shihab Islam Mensyaratkan Demokrasi”, Edisi 09 januari 2009, http:/ / Republika.co.id, diakses 21 November 2020. 
pula dibenarkan menetapan hal yang bertentangan dengan prinsip-prinsip ajaran Ilahi.

Kata أَمْرُهُمْ (amruhum/urusan) menurut M. Quraish Shihab "menunjukkan bahwa yang dapat dimusyawarakan adalah hal-hal yang berkaitan dengan urusan yang berada dalam wewenang manusia. Masalah ibadah madhah/murni sepenuhnya berada dalam wewenang Allah tidak termasuk ke dalam hal-hal yang bisa di musyawarakan. Di sisi lain, mereka yang tidak berwenang dalam urusan dimaksud tidaklah perlu terlibat dalam musyawarah itu, kecuali jika diajak oleh yang berwenang karena boleh jadi yang mereka musyawarahkan adalah persoalan rasiah antara mereka." 34

Sebagian pakar tafsir membatasi masalah permusyawarahan hanya untuk yang berkaitan dengan urusan dunia, bukan persoalan agama. Pakar yang lain memperluas hingga membenarkan adanya musyawarah di samping untuk urusan dunia, juga untuk sebagian masalah keagamaan. Alasannya, karena dengan adanya perubahan sosial, sebagian masalah keagamaan belum ditentukan penyelesaiannya di dalam Al-Quran maupun sunnah Nabi Muhammad saw. ${ }^{35}$

Dalam demokrasi tidak ada intervensi yang berasal dari pihak luar, di luar diri manusia, yaitu Allah SWT Dengan demikian, dalam demokrasi tidak ada nilai-nilai yang bercorak ilahiah. Tidak ada nilai-nilai yang dipandang transendental yang abadi. Justifikasi benar dan salah yang dihasilkan dari demokrasi bercorak relatif, sangat bergantung kepada hasil kesepakatan bersama suatu masyarakat. Keputusan dan aturan yang dilembagakan sebagai hasil demokrasi tidak memiliki kemutlakan dan nilai transenden (spiritual). Orang yang menyatakan bahwa antara Islam dan demokrasi terdapat segi-segi persamaan, itu hanyalah berarti menerangkan sebagian dari hakekatnya; karena hakekat yang sempurna ialah, antara Islam dan demokrasi ada perbedaan. Bahkan menurutnya yang lebih tepat ialah ada hal-hal yang bersesuaian, tetapi banyak hal-hal yang tidak bersesuain ${ }^{36}$.

Dari sini disimpulkan bahwa persoalan-persoalan yang telah ada petunjuknya dari Tuhan secara tegas dan jelas, baik langsung maupun melalui Nabi-Nya, tidak dapat dimusyawarahkan, seperti misalnya tata cara beribadah. Musyawarah hanya dilakukan pada hal-hal yang belum ditentukan petunjuknya, serta persoalan-persoalan kehidupan duniawi. Persolan tersebut baik yang petunjuknya bersifat global maupun tanpa petunjuk dan yang mengalami perkembangan dan perubahan.

Nabi Muhammad SAW bermusyawarah dalam hal-hal yang berkaitan dengan urusan masyarakat dan negara, seperti persoalan perang, ekonomi, dan sosial. Bahkan dari sejarah diperoleh informasi bahwa beliaupun bermusyawarah (meminta saran dan pendapat) di dalam beberapa persoalan pribadi atau keluarga. Nabi selalu menghormati dan menghargai setiap pendapat sahabatnya, ia berlaku lemah lembut dan pemaaf serta tidak pernah

${ }^{34}$ M. Quraish Shihab, Tafsir al-Misbâh..., h. 178.

${ }^{35}$ M. Quraish Shihab, Wawasan Al-Qur'an: Tafsir Tematik..., h. 471.

36 Ash-Shiddieqy, Hasbi. Ilmu Kenegaraan dalam Figh Islam, (Jakarta: Bulan Bintang, 1991), h. 126. 
memaksakan kehendak (diktator) dalam bermusyawara walapun beliau kurang menyetujui pendapat sahabatnya seperti halnya saat perang uhud.

Syura adalah salah satu prinsip penting tentang pemerintah yang dijelaskan dalam Al-Quran. Syura mengharuskan kepala negara dan pimpinan pemerintahan untuk menyelesaikan permasalahan-permasalahan masyarakat lewat permusyawaratan dengan anggota masyarakat. Landasan syura sebagai suatu prinsip hukum umum. Permasalahan masyarakat harus ditentukan dengan musyawarah. Karena itu, syura bersifat fleksibel, tidak dibatasi dan dapat diterapkan dalam semua keadaan dan untuk semua permasalahan yang berkaitan dengan masyarakat. Ini menunjukkan bahwa demokrasi mementingkan kedaulatan rakyat. Dalam sistem ini kuasa mutlak membuat undang-undang dalam menentukan nilai-nilai dan normanorma amalan terletak di tangan rakyat. Dengan arti kata lain rakyat berhak menetukan segalanya.

Pendapat M. Quraish Shihab mengenai prinsip musyawarah ini tidak bisa diberlakukan kepada semua persoalan. Persoalan-persoalan yang telah ada petunjuknya dari Allah secara tegas dan jelas, baik langsung maupun melalui NabiNya, tidak dapat dimusyawarahkan, seperti misalnya cara-cara beribadah. Musyawarah hanya dilakukan pada hal-hal yang belum ditentukan petunjuknya, serta persoalan-persoalan kehidupan duniawi, baik yang petunjuknya bersifat global maupun tanpa petunjuk dan yang mengalami perkembangan dan perubahan. Masalah yang sudah mutlak ketentuan hukumnya yang berkaitan dengan kewajiban ibadah-ibadah mahdhah (murni), keharaman babi, judi, riba dan seterusnya.

Prosedur demokrasi, dalam hal-hal tertentu tidak bisa merubah ketentuan wajibnya ibadah shalat, puasa, zakat atau haji, karena ia merupakan persoalan yang sudah qath'i. Prosedur demokratik barangkali baru bisa dilakukan pada persoalanpersoalan yang sifatnya dzanni. Oleh karena itu, untuk memperjelas di mana letak otoritas Allah dan otoritas manusia, kiranya di sini harus dijelaskan dan dipilahkan pula persoalan-persoalan yang masuk ke dalam dua kategori tadi, qath'i dan dzanni.

Dengan menggunakan kerangka pikir yang dikemukakan oleh Qursih Shihab bahwasanya suatu ayat dapat menjadi qath'i dan dzanni pada saat yang sama, memberi kesempatan kepada umat Islam untuk mengadaptasikan pokokpokok pikiran tertentu dalam Al-Quran dengan perkembangan politik modern, demokrasi misalnya. Pada dataran pikiran ini gagasan wakil kedaulatan Allah dapat dioperasionalkan melalui konstitusionalisme. Melalui mekanisme ini dapat ditentukan peraturan perundang-undangan yang dimaksudkan sebagai cara untuk mengatur kehidupan suatu negara, apakah itu berkaitan dengan mekanimse pemilihan presiden, lembaga-lembaga pemerintahan atau pemilihan umum. Dasar pijakan qath'i penyelenggaraan mekanisme ini dinamakan syura.

Dapat dilihat bahwa M. Quraish Shihab berpendapat Islam berbeda dengan demokrasi apabila demokrasi didefinisikan secara prosedural seperti dipahami dan dipraktekkan di negara-negara barat. M. Quraish Shihab tidak memberikan pengertian demokrasi, sebab demokrasi itu menurutnya mempunyai pengertian yang beragam. Beliau menjelaskan keputusan diambil berdasarkan pandangan mayoritas merupakan ciri umum dari demokrasi. Keputusan yang diambil berdasarkan pandangan mayoritas menurut M. Quraish Shihab disebut syura. Menurut M. Quraish 
Shihab syura dan demokrasi merupakan wacana yang mengalami perkembangan. Bentuk dan polanya disesuaikan dengan keadaan dan kondisi masyarakat. Hal ini berdasarkan pada penafsiran ayat-ayat yang memiliki kaitan dengan pembahasan syura. Dengan demikian M. Quraish Shihab termasuk kepada kelompok ulama yang kedua yang memandang demokrasi sebagai konsep yang sejalan dengan Islam setelah diadakan penyesuain penafsiran terhadap konsep demokrasi itu sendiri.

Secara umum dapat disimpulkan bahwa karakteristik pemikiran M. Quraish Shihab adalah seorang bersifat rasional dan moderat. Sifat rasional pemikirannya tidak memaksakan agama mengikuti kehendak realitas kontemporer. Disamping itu menurut penulis gagasan-gagasan yang dikeluarkan oleh M. Quraish Shihab memberikan kebebasan bagi masyarakat untuk memilih, misalnya kebebasan dalam pemakain jilbab karena jilbab merupakan pakaian kehormatan dan tidak ada kewajiban untuk memakai jilbab. M. Quraish Shihab lebih mencoba memberikan penjelasan atau signifikans khazanah agama klasik bagi masyarakat kontemporer atau mengapresiasi kemungkinan pemahaman dan penafsiran baru tetapi dengan tetap sangat menjaga kebaikan tradisi lama. Dengan kata lain, dia tetap berpegang pada adagium ulama memelihara tradisi lama yang masih relevan dan mengambil tradisi baru yang lebih baik.

\section{Simpulan}

Pandapat M. Quraish Shihab tentang demokrasi dapat ditarik kesimpulan bahwa di Islam ada prinsip-prinsip dasar demokrasi yakni adanya jaminnya terhadap hak-hak individu manusia. M. Quraish Shihab membahas tentang demokrasi ini ketika ia menafsirkan ayat tentang syura. Ada tiga ayat yang secara jelas menyebut kata syura yang secara tersirat berisi pesan untuk mengutamakan sistem demokrasi dalam segala aspek kehidupan yaitu: al-Baqaroh ayat 233, Āli 'Imrān ayat 159, asySyūrā ayat 38. Ada poin-poin penting yang dapat diambil dari penafsiran M. Quraish Shihab terhadap ketiga ayat atas. Pertama, musyawarah dimulai dari tingkat yang paling kecil dalam kehidupan bermasyarakat yakni keluarga. Ayat ini mengajarkan bagaimana seharusnya hubungan suami istri saat mengambil keputusan yang berkaitan dengan rumah tangga dan anak untuk kemaslahatan bersama. Kedua, sikap yang harus diambil setelah adanya kesepakatan dan bulatnya tekat adalah berlaku lemah lembut, memaafkan dan bertawakal kepada Allah. Ketiga, Batasan masalah yang bisa dimusyawarakan hanya pada urusan yang belum ada ketentuannya dalam Al-Quran dan Sunnah. Ketiga poin tersebut dapat menjadi pedoman dalam bermusyawarah agar mendapatkan tujuan dari musyawarah. M. Quraish Shihab membedakan demokrasi dengan syura dari tiga sudut pandang yaitu: Pertama, pihak yang mengikut musyawarah adalah orang yang memiliki akhalak yang mulia. Ini merupakan salah satu perbedaan syura di dalam Islam dengan demokrasi secara umum. Sifat yang dimaksud disini adalah sikap lemah lembut, tidak kasar, tidak berhat keras dan pemaaf (berhati lapang). Sedangkan demokrasi tidak seperti itu, anggotanya dipilih oleh rakyat, merekalah yang mencalonkan para perwakilan mereka. Setiap anggota masyarakat, siapapun dia memiliki hak untuk dicalonkan dan mencalonkan, baik dia seorang kafir, fasik (pelaku maksiat), ataupun sekuler. Kedua, dari segi pengangkatan pimpinan. Syura dan demokrasi menetapkan bahwa 
pimpinan diangkat melalui kontrak sosial, namun syura di dalam Islam mengaitkannya dengan 'perjanjian ilahi,' Seorang pemimpin yang dilantik mengikut sistem syura adalah seorang pemimpin yang mempunyai keperibadian yang baik serta bukan dari kalangan orang yang fasik maupun munafik berdasarkan apa yang telah disarankan oleh Allah SWT dalam Al-Quran. Sedangakan Demokrasi pada umumnya pemimpin diangkat berdasarkan pilihan rakyat yang telah memenuhi syarat yang di berikan negara. Ketiga, persoalan yang dapat dibahas dan diputuskan, di dalam sistem demokrasi sekuler persoalan apapun dapat dibahas dan diputuskan. Tetapi dalam syura yang diajarkan dalam Islam, tidak dibenarkan untuk memusyarakan segala sesuatu yang telah ada ketetapannya dan tidak pula dibenarkan menetapan hal yang bertentangan dengan prinsip-prinsip ajaran Ilahi. M. Quraish Shihab termasuk kepada kelompok ulama yang kedua yang memandang demokrasi sebagai konsep yang sejalan dengan Islam setelah diadakan penyesuain penafsiran terhadap konsep demokrasi itu sendiri. Secara umum dapat disimpulkan bahwa karakteristik pemikiran M. Quraish Shihab adalah seorang bersifat rasional dan moderat. Sifat rasional pemikirannya tidak memaksakan agama mengikuti kehendak realitas kontemporer. M. Quraish Shihab lebih mencoba memberikan penjelasan atau signifikans khazanah agama klasik bagi masyarakat kontemporer atau mengapresiasi kemungkinan pemahaman dan penafsiran baru tetapi dengan tetap sangat menjaga kebaikan tradisi lama. Dengan kata lain, dia tetap berpegang pada adagium ulama memelihara tradisi lama yang masih relevan dan mengambil tradisi baru yang lebih baik.

\section{Referensi:}

Al Qurthubī, al-Jami' li Ahkām al-Qur'an, Terj. Dudi Rosyadi dkk, Jakarta: Pustaka Azzam, 2008.

Al-Mawārdi, Al-ahkam As-sulthaniyyah, Bairut: Dar al-Fikr, 2016.

Al-Zuhaili, Wāhbāh, Qadāyā al-Fiqh wa al-Mu'asìr, (Damaskus: Darl Fikr, 2006.

Al-Zuhāilī, Wāhbāh, Tafsìr al-Munìr Fì al-'Āqìdah wa al-Syarī'āh Wa al-Manhāj, Beirut: Dār al-Fikr. 2009.

Ash-Shiddieqy, Hasbi, Ilmu Kenegaraan dalam Figh Islam, Jakarta: Bulan Bintang, 1991.

Damanhuri Zuhri, "Prof. Dr. H. M. Quraish Shihab Islam Mensyaratkan Demokrasi Jum'at", Edisi 09 januari 2009. http://Republika.co.id diakses 21 November 2020.

Departemen Agama RI, Al-Qur'an dan Terjemahannya, Jakarta: Pustaka Alfatih, 2009. Hamka, Tafsir Al-Azhar,Jakarta: Pustaka Panjimas, 1984.

Idris Thaha, Demokrasi Religius: Pemikiran Politik Nurcholish Madjid dan Amien Rais, Jakarta: Teraju 2005.

M. Quraish Shihab, Tafsìr al-Misbāh: Pesan Kesan dan Keserasian al-Qur'an, Jakarta: Lentera Hati, 2002.

M. Quraish Shihab, Wawasan Al-Qur'an: Tafsir Tematik atas Berbagai Persoalan Umat, Bandung: Mizan, 2007.

Salim Ali al-Bahansawi, Wawasan Sistem Politik Islam Asy Syari'ah al-Muftara 'Alaiha, Terj. Mustolah Maufur, Jakarta: Pustaka al-Kautsar, 1996. 
Ubaedillah. dkk, Pendidikan Kewargaan (Civic Education) Demokrasi Hak Asasi Manusia dan Masyarakat Madani, Jakarta: ICCE UIN Syarif Hidayatullah, 2000.

Wikipedia.org, "Muhammad Quraish Shihab", https://id.m.wikipedia.org /wiki/Muhammad_Quraish_Shihab diakses 21 November 2020.

Zūhailī, Qadāyā al-Fiqh wa al-Mu'asìr, Damaskus: Darl Fikr, 2006. 